\title{
Swiss Stained-Glass Panels: An Analytical Study
}

\author{
Andreia Machado ${ }^{1,2}$ Sophie Wolf, ${ }^{3}$ Luis C. Alves, ${ }^{4}$ Ildiko Katona-Serneels, ${ }^{5}$ Vincent Serneels, ${ }^{5}$ \\ Stefan Trümpler, ${ }^{3}$ and Márcia Vilarigues ${ }^{1,2, *}$ \\ ${ }^{1}$ RひD Unit, Vidro e da Cerâmica Para as Artes (VICARTE), Faculdade de Ciências e Tecnologia, Universidade Nova \\ de Lisboa, Hangar III, Campus da Caparica, 2829-516 Caparica, Portugal \\ ${ }^{2}$ Department of Conservation and Restoration, Faculdade de Ciências e Tecnologia, Universidade NOVA de Lisboa, Campus \\ da Caparica, 2829-516 Caparica, Portugal \\ ${ }^{3}$ Vitrocentre Romont, Au Château, P.O. Box 225, CH-1680 Romont, Switzerland \\ ${ }^{4}$ C2TN, IST/CTN, University of Lisbon, E.N. 10, 2686-953 Sacavém, Portugal \\ ${ }^{5}$ Department of Geosciences, University of Fribourg, Chemin du Musée 6, 1700 Fribourg, Switzerland
}

\begin{abstract}
The history and iconography of Swiss stained glass dating between the 16th and 18th centuries are well studied. However, the chemical and morphological characteristics of the glass and glass paints, particularly the nature of the raw materials, the provenance of the glass, and the technology used to produce it are less well understood. In this paper, we studied two sets of samples from stained-glass panels attributed to Switzerland, which date from the 16th to 17th centuries: the first set comes from Pena National Palace collection, the second from Vitrocentre Romont. The aims were to identify the materials used in the production of the glass, to find out more about their production origin and to characterize the glass paints. Both glass and the glass paints were analysed by particle-induced X-ray emission; the paints were additionally analysed by scanning electron microscopy-electron-dispersive X-ray spectroscopy (SEM-EDS). The results show that the glass from both sets was probably produced in the same region and that wood ash was used as a fluxing agent. Different recipes have been used to make the blue enamels. However, the cobalt ore used as a coloring agent in all of the blue enamels came from the mining district in Schneeberg, Germany.
\end{abstract}

Key words: stained glass, Switzerland, Portugal, $\mu$-PIXE, SEM-EDS

\section{INTRODUCTION}

\section{Historical Background and Aim of the Study}

Most Swiss stained glass of the modern period are single stained-glass panels, also known as Wappenscheiben (Caviness, 2010). By the end of the 15th century, the custom to donate such panels for public or private buildings was widespread in Switzerland (Giesicke \& Ruoss, 2000). Their production reached its peak in the 16th and 17th centuries, when a great number of glass painter's workshops were active in Switzerland, but had faded by the 18th century. The panels usually show the coat of arms of the donor, and sometimes also his portrait; they depict religious themes or scenes of everyday life such as representations of artisans at work. Illustrations of local history and legends are also frequent motifs (Hasler \& Trümpler, 1998; Bergmann et al., 2006). The early panels were usually made with traditional materials, using grisaille and silver stain as glass paints. From the second half of the 16th century onwards, the use of enamel paints became widespread.

During the 18th century, when stained glass windows fell out of fashion, many of the stained-glass panels were replaced by clear glass; few survived in their original locations. Most of the dismantled panels were destroyed or

${ }^{*}$ Corresponding author. mgv@fct.unl.pt sold on the flourishing art market between end of the 18th century and the late 19th century, which is how many Swiss panels came to be in museums and private collections (Schneider, 1971; Giesicke \& Ruoss, 2000).

There is evidence for both glass production and glass working in Switzerland from the Middle Ages through to the modern period. The 26 glasshouses identified in the Jura region, for example, which were active between the late 14th and the mid-19th centuries, produced vessel as well as colorless window glass from local raw materials (Gerber, 2010; Gerber \& Stern, 2012). They supplied the local markets with glassware and window glass, but it is unclear whether the production was sufficient to meet demand. Written sources from the 16th and 17th centuries record the importation of colored window glass from the Lorraine region and state that the best red glass came from Burgundy. The glass was transported by ship via Basel and was traded on local markets (Hasler, 2010; Bergmann, 2014, 2016). The trade in colorless and colored sheet glass was subject to strict trade regulations, for example, the amount of glass that could be purchased by the glass painters was fixed (Bergmann, 2014).

The main aim of this study was to determine the compositions of the glass and the glass paints from a number of single stained-glass panels, assumed to be of Swiss origin and dating from the early modern period. In particular, we intended to identify the nature of the raw materials used in the production of the panels. We focused on stained-glass 
panels dating from the 16th and 17th centuries. The panels analysed are now in the collections at the Pena National Palace, Portugal and the Vitrocentre Romont, Switzerland. One of the questions to be answered using the compositional data was whether the panels from the Portuguese and Swiss collections were produced in the same region, and whether similar techniques and paint recipes were used for the glass paints. Another objective was to discover whether the uncolored and the colored sheet glass were produced in the same or in different regions-as suggested by 16 th and 17 th centuries sources (see above).

To determine the nature of the raw materials used in the production of the glass, the elements associated with the silica source (e.g., alumina, iron, titanium) as well as those related to the alkali sources (e.g., phosphorous, potassium, calcium) were analysed by particle-induced X-ray emission ( $\mu$-PIXE). The chemical composition and morphological characteristics of the glass paints, which provide insights into the nature of materials and recipes, was determined by $\mu$-PIXE as well as by scanning electron microscopyelectron-dispersive X-ray spectroscopy (SEM-EDS).

\section{Materials Studied}

The 21 samples selected for analysis were taken from small fragments belonging to stained-glass panels of two collections: the first set of six samples comes from the Pena National Palace collection (PNP set) (Fig. 1), the second set comprising 15 samples comes from Vitrocentre Romont (VCR set).

The PNP samples were taken from glass fragments that belong to panels in the private collection of stained glass of King Ferdinand II (1816-1885), which is currently on display at the Pena National Palace, Portugal (Martinho \& Vilarigues, 2011). The fragments were found after the restoration of their respective stained-glass panels and were thus not included in the restored panels, which were already on display when the missing fragments were discovered. This was a good opportunity to study their glass composition.
The VCR samples come from a collection of loose stained-glass fragments held at the Vitrocentre Romont; the collection is part of the bequest of Hans Meyer, a stainedglass painter who worked in Zurich between 1893 and 1961. Hans Meyer also restored "Wappenscheiben," and for this purpose had collected fragments of broken or discarded historic stained-glass panels (Schneider, 1978). The selection of fragments was based on their typology and the painting techniques applied, which are specific to a region and period and therefore allow an attribution of date and Swiss provenance (Lehmann, 1941; Boesch, 1955).

Description of the Fragments from the Pena National Palace This set (Fig. 2a, Table 1) consists of six fragments of colorless stained glass, painted with grisaille, yellow silver stain and blue enamel. One of the fragments (PNP16) also includes an area with red flashed glass (glass consisting of a thin layer of red glass over a layer of colorless glass). The grisaille is always applied to the front of the stained glass, while the yellow silver stain and the blue enamel are applied to the back.

Sample PNP05 probably belongs to the heraldic panel with the coat of arms of the canton of Luzern dating to 1688 (cf. Fig. 1b). However, it is also possible that it was part of the panel inscribed with Ioannes Heinricus Fleischlin, which also dates to 1688 (PNP2820) (cf. Fig. 1c); both panels originally come from the church of St. Gallus and Otmar in Kriens, Luzern. Sample PNP16 comes from panel PNP2860, a 17th-century heraldic panel with the coat of arms of Niedersimmental (cf. Fig. 1a). PNP17 has also been attributed to the aforementioned panel PNP2820. Samples PNP06, PNP07, and PNP12 could unfortunately not be attributed to any of the existing panels in the collection. These fragments might have originated in one or more panels, which are known to have been lost from the collection. However, they may also have been used as stopgaps during a past restoration of the extant panels and subsequently been removed. There is evidence of such use of historic fragments as stopgaps within the collection. For example, panel

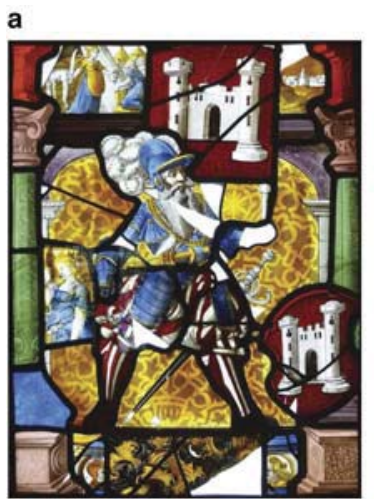

b

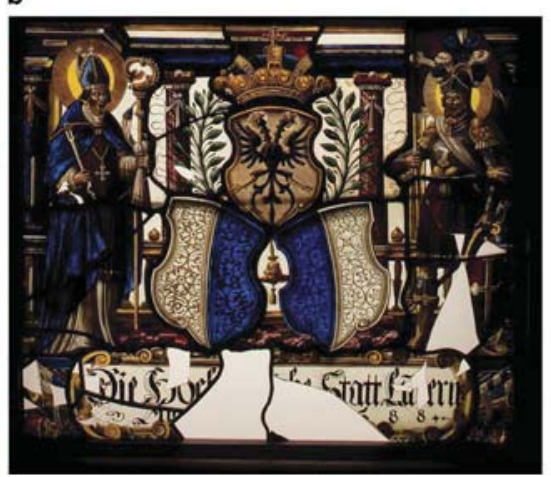

c

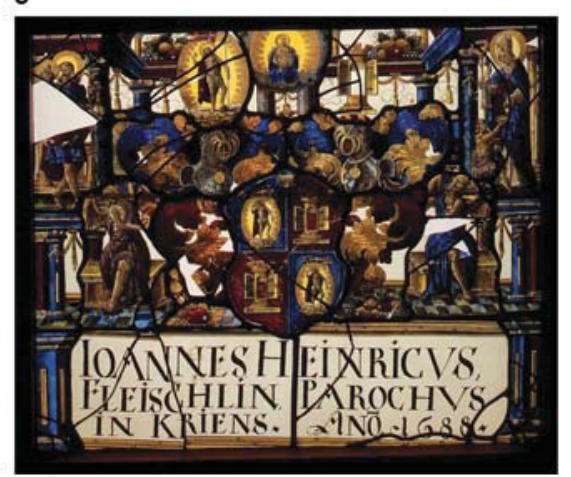

Figure 1. Swiss stained-glass panels from the Pena National Palace (PNP) collection. a: Heraldic panel with the coat of arms of Niedersimmental, 17th century (PNP2860), (b) Heraldic Panel with the coat of arms of the canton of Luzern, 1688 (inscribed) (PNP2808), and (c) Heraldic panel of Ioannes Henricus Fleischlin, 1688 (inscribed) (PNP2820). ${ }^{\circ}$ Luís Pavão, Parques de Sintra, Monte da Lua, S.A. 


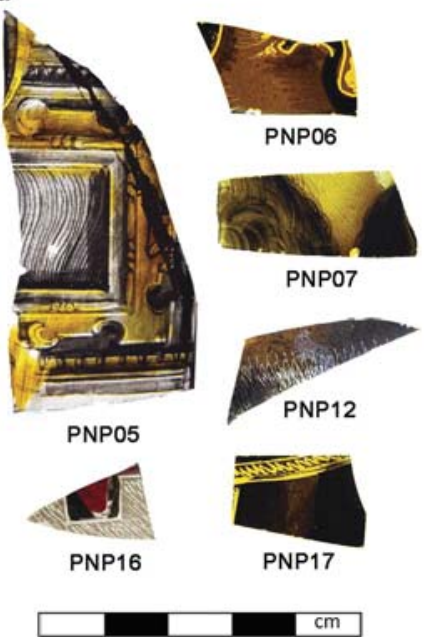

b

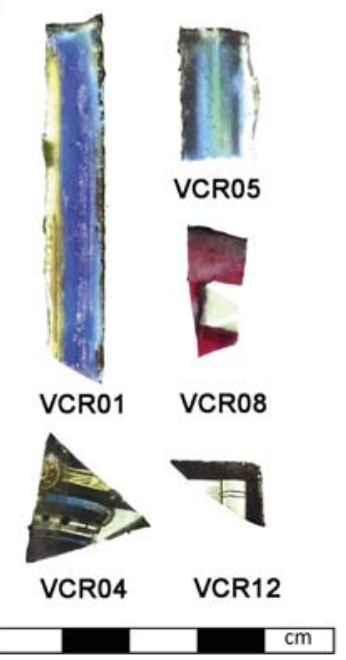

Figure 2. Material analysed: (a) the six stained-glass fragments from the collection at Pena National Palace; (b) five of the 15 fragments from the collection at Vitromusée Romont.

qPNP2860 (cf. Fig. 1a), contains pieces, which probably originated in several other lost historic stained-glass panels. Although the precise origins of samples PNP06, PNP07, and PNP12 are unknown, the design and painting techniques they exhibit leave no doubt that they are Swiss and date to the early modern period.

\section{Description of the Fragments from Vitrocentre Romont}

This set (cf. Fig. 2b, Table 2) includes 11 stained-glass fragments consisting of colorless glass painted with grisaille, yellow silver stain, and/or blue enamel (Table 2, VCR01-08 and VCR11-13). One of the fragments is also painted with sanguine (red) (VCR06), a pigment obtained from red iron oxide, which can be applied either as a transparent wash or an opaque color. Two of the colorless fragments also include areas of red flashed glass (VCR07 and VCR08).
The set also includes four colored glass fragments. The purple colored glass (VCR09, VCR14, and VCR15) is composed of red and blue flashed glass and the light brown glass (VCR10) consists of colorless and purple flashed glass. Two of the colored glass fragments are painted with grisaille.

As with the fragments from Portugal, the grisaille is applied to the front of the glass, and the yellow silver stain, blue enamels and sanguine are applied to the back.

\section{Experimental Procedure}

In order to determine the compositions of the bulk glass and the glass paints and for a better assessment of the morphological characteristics of the paint layers, we took small samples ( $\sim 5 \mathrm{~mm}$ in width) from the stained-glass fragments. The samples were analysed by $\mu$-PIXE and by SEM-EDS; the latter method was also used to measure the elemental distribution (X-ray maps) and to show the structural characteristics of the paint layers [backscattered electron image mode (BSE)].

PIXE analysis has been widely used for the study of the chemical composition of glass (Šmit et al., 2005; Coutinho et al., 2016). By using an internal ion beam in a vacuum, important low $\mathrm{Z}$ elements such as sodium and aluminum are also detectable. This technique does not leave any undesirable alterations to the glass, unlike other analytical techniques such as inductively coupled plasma mass spectrometry (ICP-MS), which can leave craters of ca. $100 \mu \mathrm{m}$ in diameter. In addition, PIXE can perform analysis of selected areas of very small size, which can be important for the determination of the chemical composition of heterogeneous surfaces, for example, of grisaille and enamels. Like SEM-EDS, PIXE can also be used to produce $\mathrm{X}$-ray maps showing the elemental distribution in the sample; however, SEM-EDS combined with BSE imaging produces higher resolution images, which enable the morphological characteristics of the samples to be highlighted (Janssens, 2013).

Table 1. Set of Stained-Glass Fragments From Pena National Palace (PNP) Analysed by Particle-Induced X-Ray Emission and Scanning Electron Microscopy/Electron-Dispersive X-Ray Spectroscopy.

\begin{tabular}{|c|c|c|}
\hline Stained-Glass Panel & Glass Color and Paints & Sample \\
\hline $\begin{array}{l}\text { PNP2808, heraldic panel with the coat of arms of } \\
\text { the canton of Luzern } \\
1688 \text { (inscribed) }\end{array}$ & Colorless glass painted with grisaille and yellow silver stain & $\mathrm{PNP}^{\mathrm{a}}{ }^{\mathrm{a}}$ \\
\hline $\begin{array}{l}\text { PNP2820, Ioannes Henricus Fleischlin } \\
1688 \text { (inscribed) }\end{array}$ & $\begin{array}{l}\text { Colorless glass painted with grisaille, yellow silver stain, and blue } \\
\text { enamel }\end{array}$ & PNP17 \\
\hline $\begin{array}{l}\text { PNP2860, heraldic panel with the coat of arms of } \\
\text { Niedersimmental } \\
17^{\text {th }} \text { century }\end{array}$ & Colorless painted with grisaille and red flashed glass & PNP16 \\
\hline \multirow{3}{*}{$\begin{array}{l}\text { Unknown or lost stained-glass panels } \\
16^{\text {th }} \text { and } 17^{\text {th }} \text { centuries }\end{array}$} & Colorless glass painted with grisaille and yellow silver stain & PNP06 \\
\hline & Colorless glass painted with grisaille & PNP07 \\
\hline & $\begin{array}{l}\text { Colorless glass painted with grisaille, yellow silver stain, } \\
\text { and blue enamel }\end{array}$ & PNP12 \\
\hline
\end{tabular}

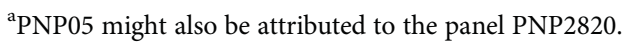


Table 2. Stained-Glass Samples From Vitrocentre Romont (VCR) Analysed by Particle-Induced X-Ray Emission and Scanning Electron Microscopy/Electron-Dispersive X-Ray Spectroscopy.

Samples Glass Color and Paints

VCR01 Colorless glass painted with grisaille and blue enamel

VCR02 Colorless glass painted with blue enamel

VCR03 Colorless glass painted with grisaille, yellow silver stain, and blue enamel

VCR04

VCR05 Colorless glass painted with grisaille and blue enamel

VCR06 Colorless glass painted with grisaille and red sanguine

VCR07 Colorless glass painted with grisaille and red flashed glass

VCR08

VCR09 Purple glass consisting of blue and red flashed glass, painted with grisaille

VCR10 Light brown glass consisting of colorless and purple flashed glass, painted with grisaille

VCR11 Colorless glass painted with grisaille

VCR12

VCR13

VCR14 Purple glass consisting of blue and red flashed glass

VCR15

\section{Sample Preparation}

Polished cross-sections of all of the samples were prepared by cutting a small piece of $\sim 5 \mathrm{~mm}$ of each sample and mounting it in epoxy resin (Araldite $2020^{\circledR}$ ). The preparation of the stainedglass samples for SEM-EDS analysis was performed separately for both sets: VCR samples were polished flat with a $0.5 \mu \mathrm{m}$ diamond paste and then coated with a thin carbon layer. PNP samples were polished up using a 12,000 grit and coated with a thin $\mathrm{Au} / \mathrm{Pd}$ layer. The different coatings on the glass samples did not seriously influence the results and the morphological characteristics of the glass paints were clearly visible.

\section{$\mu$-PIXE}

For the $\mu$-PIXE analysis, the ion beam analytical facilities at the Instituto Superior Técnico (IST), Pólo de Loures, were used. They comprise a 2.5 MV Van de Graaff accelerator and an OM150 Oxford Microbeam scanning nuclear microprobe. The stained-glass fragments embedded in resin were irradiated with focused proton beams (down to $3 \times 4 \mu \mathrm{m}^{2}$ ) in a vacuum. A $145 \mathrm{eV}$ resolution silicon drift X-ray detector was used to obtain sample X-ray spectra. With the microprobe beam scanning system, elemental distribution maps were obtained and specific regions of interest selected for quantitative analysis. The samples were irradiated both with a $1 \mathrm{MeV}$ proton beam (no filter) to obtain concentrations of $\mathrm{Na}, \mathrm{Mg}$, and $\mathrm{Al}$, and with a $2 \mathrm{MeV}$ proton beam (using a $50 \mu \mathrm{m}$ Mylar filter in front of the X-ray detector) for trace element quantification (for elements heavier than $\mathrm{Fe}$ ). Operation and basic data manipulation was achieved using OMDAQ software (Grime \& Dawson, 1995); quantitative analysis was performed with the GUPIX program (Campbell et al., 2010).
The results-the given weight percentage of the element oxide-were normalized to $100 \%$. The trace element concentrations analysed at $2 \mathrm{MeV}$ were normalized to the iron content (Bellot-Gurlet et al., 2005). When determining the base glass composition of the colored glass, we removed the coloring elements (e.g., $\mathrm{Cu}, \mathrm{Co}, \mathrm{Mn}$ ) from the data set and again normalized to $100 \%$.

Two glass reference standards were also analysed (Corning B and Corning C). The parameters used to obtain their respective concentration were used to determine the final composition of the stained-glass samples.

\section{SEM-EDS}

The stained-glass samples from VCR set were analysed by SEM-EDS at the Geosciences Department at the University of Fribourg. The equipment used was a Philips ${ }^{\circledR}$ FEI XL30 Sirion field emission gun (FEG) scanning electron microscope (FEI, Eindhoven, The Netherlands), operated at a beam acceleration voltage of $20 \mathrm{kV}$ and a beam current of $5 \mathrm{nA}$. A backscattered electron detector was used for imaging. X-ray maps were collected using an energy-dispersive $\mathrm{X}$-ray spectrometry system from EDAX.

The samples from the PNP set were analysed at the MicroLab Electron Microscopy Laboratory, at IST in Lisbon. The equipment used was a FEG-SEM from JEOL (JEOL, Tokyo, Japan), model JSM7001F, operating at a beam acceleration voltage of $20 \mathrm{kV}$, using a backscattered electron detector for imaging. X-ray maps were collected using an INCA 250 energy-dispersive X-ray spectrometer system from Oxford Instruments (Oxford Instruments, Abingdon, England).

\section{Results And Discussion}

\section{Composition of the Glass}

The $\mu$-PIXE results obtained for the composition of the glass are presented in Table 3. According to the literature (Schalm et al., 2007; Wedepohl \& Simon, 2010), the compositions of the glass-comprising the samples from both sets-can be subdivided into two groups: the first group, which includes 13 samples, has a high lime-low alkali composition (HLLA), with a $\mathrm{K}_{2} \mathrm{O} / \mathrm{CaO}$ ratio between 0.2 and 0.4 . The second group, comprising six samples, is composed of a potassiumrich glass with high calcium content, with a $\mathrm{K}_{2} \mathrm{O} / \mathrm{CaO}$ ratio between 0.6 and 1.2 and concentration above $9.5 \mathrm{wt} \%$ for both $\mathrm{K}_{2} \mathrm{O}$ and $\mathrm{CaO}$. One sample (PNP06) stands out for its very high potassium and lower calcium concentration (19.4 wt\% of $\mathrm{K}_{2} \mathrm{O}$ and $8.6 \mathrm{wt} \%$ of $\mathrm{CaO}$ ), another sample (VCR06) for its elevated sodium content ( $8 \mathrm{wt} \% \mathrm{Na}_{2} \mathrm{O}$ and a $\mathrm{K}_{2} \mathrm{O} / \mathrm{Na}_{2} \mathrm{O}$ of 0.3 ) (Fig. 3).

In the HLLA group, the $\mathrm{K}_{2} \mathrm{O}$ concentration varies between 3.4 and $7.3 \mathrm{wt} \%, \mathrm{CaO}$ ranges from 17.4 to $22.3 \mathrm{wt} \%$, and the $\mathrm{Na}_{2} \mathrm{O}$ concentration is between 0.65 and $3 \mathrm{wt} \%$. The $\mathrm{MgO}$ concentration varies between 2.7 and $4.5 \mathrm{wt} \%, \mathrm{P}_{2} \mathrm{O}_{5}$ ranges from $1.8 \mathrm{wt} \%$ up to $2.8 \mathrm{wt} \%$, and $\mathrm{Al}_{2} \mathrm{O}_{3}$ between 2.9 and $5.5 \mathrm{wt} \%$. This group comprises all the colorless glass with the exception of samples VCR03, PNP06, and PNP07. 
Table 3. Particle-Induced X-Ray Emission Results for the Glass From Vitrocentre Romont (VCR) and Pena National Palace (PNP) Sets (wt\%).

\begin{tabular}{|c|c|c|c|c|c|c|c|c|c|c|c|c|c|c|c|c|c|c|c|c|c|c|}
\hline Samples & Color & $\mathrm{Na}_{2} \mathrm{O}$ & $\mathrm{MgO}$ & $\mathrm{Al}_{2} \mathrm{O}_{3}$ & $\mathrm{SiO}_{2}$ & $\mathrm{P}_{2} \mathrm{O}_{5}$ & $\mathrm{SO}_{3}$ & $\mathrm{Cl}$ & $\mathrm{K}_{2} \mathrm{O}$ & $\mathrm{CaO}$ & $\mathrm{TiO}_{2}$ & $\mathrm{MnO}$ & $\mathrm{Fe}_{2} \mathrm{O}_{3}$ & $\mathrm{CoO}$ & $\mathrm{NiO}$ & $\mathrm{CuO}$ & $\mathrm{ZnO}$ & $\mathrm{As}_{2} \mathrm{O}_{5}$ & $\mathrm{Rb}_{2} \mathrm{O}$ & $\mathrm{SrO}$ & $\mathrm{BaO}$ & $\mathrm{K}_{2} \mathrm{O} / \mathrm{CaO}$ \\
\hline VCR01 & Colorless & 0.4 & 3.4 & 4.4 & 58.0 & 2.56 & 0.15 & 0.05 & 6.29 & 22.33 & 0.23 & 0.72 & 1.02 & n.d. & $<0.01$ & 0.01 & 0.02 & 0.02 & $<0.01$ & 0.06 & 0.26 & 0.28 \\
\hline VCR02 & Colorless & 0.5 & 3.9 & 4.7 & 61.5 & 2.15 & 0.14 & 0.05 & 6.59 & 17.77 & 0.24 & 0.90 & 0.90 & n.d. & n.d. & 0.01 & 0.02 & 0.03 & $<0.01$ & 0.06 & 0.47 & 0.37 \\
\hline VCR03 & Colorless & 0.4 & 3.6 & 3.0 & 61.6 & 1.49 & 0.30 & 0.02 & 9.67 & 17.26 & 0.14 & 1.18 & 0.49 & n.d. & n.d. & 0.02 & 0.03 & n.d. & $<0.02$ & $<0.04$ & 0.69 & 0.56 \\
\hline VCR04 & Colorless & 0.8 & 4.5 & 5.5 & 58.7 & 2.63 & 0.06 & 0.21 & 7.23 & 17.91 & 0.23 & 0.55 & 1.18 & n.d. & n.d. & 0.01 & 0.04 & 0.03 & $<0.01$ & $<0.02$ & 0.22 & 0.40 \\
\hline VCR05 & Colorless & 0.5 & 3.9 & 4.7 & 62.0 & 2.16 & 0.14 & 0.05 & 6.48 & 17.42 & 0.21 & 0.86 & 0.88 & n.d. & n.d. & 0.01 & 0.02 & 0.03 & $<0.01$ & 0.05 & 0.46 & 0.37 \\
\hline VCR06 & Colorless & 8.3 & 0.8 & 1.9 & 68.5 & 0.28 & 0.57 & 0.42 & 2.78 & 15.33 & 0.11 & 0.11 & 0.35 & n.d. & $<0.01$ & 0.003 & 0.01 & 0.02 & $<0.01$ & $<0.01$ & 0.02 & 0.18 \\
\hline \multirow[t]{2}{*}{ VCR07 } & Colorless & 1.2 & 3.8 & 4.5 & 59.6 & 2.23 & 0.18 & 0.24 & 5.88 & 20.04 & 0.19 & 0.74 & 0.83 & n.d. & n.d. & 0.01 & 0.02 & $<0.01$ & $<0.01$ & 0.06 & 0.26 & 0.29 \\
\hline & Red & 1.1 & 3.7 & 4.6 & 59.3 & 2.24 & $<0.03$ & 0.22 & 6.02 & 19.71 & 0.18 & 0.69 & 0.84 & n.d. & n.d. & 0.67 & 0.02 & 0.01 & $<0.01$ & 0.07 & 0.28 & 0.31 \\
\hline \multirow[t]{2}{*}{ VCR08 } & Colorless & 0.7 & 3.5 & 4.2 & 61.6 & 2.21 & 0.21 & 0.12 & 6.20 & 19.13 & 0.20 & 0.81 & 0.82 & n.d. & 0.01 & 0.01 & 0.02 & 0.01 & $<0.01$ & 0.05 & 0.33 & 0.32 \\
\hline & Red & 0.7 & 3.5 & 4.3 & 61.2 & 2.15 & 0.21 & 0.09 & 6.41 & 19.34 & 0.19 & 0.79 & 0.87 & n.d. & 0.02 & 0.62 & 0.03 & 0.02 & $<0.01$ & 0.05 & 0.33 & 0.33 \\
\hline \multirow[t]{2}{*}{ VCR09 } & Red & 0.4 & 3.2 & 3.40 & 56.4 & 1.46 & 0.32 & $<0.01$ & 11.58 & 18.79 & 0.15 & 2.79 & 0.48 & $<0.01$ & $<0.01$ & 0.01 & 0.02 & $<0.01$ & $<0.01$ & 0.08 & 0.75 & 0.62 \\
\hline & Blue & 0.4 & 3.4 & 3.2 & 58.6 & 1.47 & 0.30 & $<0.02$ & 10.96 & 18.54 & 0.16 & 1.10 & 0.77 & 0.17 & 0.05 & 0.01 & 0.01 & 0.31 & $<0.01$ & 0.05 & 0.49 & 0.59 \\
\hline \multirow[t]{2}{*}{ VCR10 } & Colorless & 0.4 & 3.2 & 3.9 & 60.0 & 1.20 & 0.24 & 0.03 & 15.28 & 13.89 & 0.17 & 1.24 & 0.36 & n.d. & n.d. & $<0.01$ & 0.02 & $<0.01$ & $<0.01$ & 0.10 & 0.43 & 1.10 \\
\hline & Purple & 0.5 & 3.3 & 3.9 & 57.4 & 1.21 & 0.30 & 0.03 & 14.88 & 14.30 & 0.20 & 2.94 & 0.55 & 0.02 & 0.01 & 0.01 & 0.02 & 0.03 & $<0.01$ & 0.10 & 0.43 & 1.04 \\
\hline CR11 & Colorless & 2.9 & 3.0 & 2.9 & 62.5 & 2.72 & 0.11 & 0.59 & 3.38 & 19.74 & 0.13 & 0.52 & 0.56 & n.d. & $<0.01$ & 0.02 & 0.03 & $<0.01$ & $<0.01$ & 0.07 & 0.09 & 0.17 \\
\hline VCR12 & Colorless & 2.1 & 3.2 & 5.4 & 59.1 & 1.81 & 0.08 & 0.43 & 5.30 & 19.76 & 0.25 & 0.77 & 0.84 & n.d. & 0.01 & 0.01 & 0.03 & 0.03 & $<0.01$ & 0.09 & 0.24 & 0.27 \\
\hline VCR13 & Colorless & 2.7 & 2.9 & 2.9 & 62.7 & 2.80 & 0.10 & 0.60 & 3.37 & 19.73 & 0.16 & 0.51 & 0.53 & n.d. & $<0.01$ & 0.02 & 0.03 & $<0.01$ & $<0.01$ & 0.07 & 0.09 & 0.17 \\
\hline \multirow{2}{*}{ VCR14 } & Red layer & 0.7 & 3.5 & 2.8 & 58.4 & 1.18 & 0.35 & 0.06 & 14.13 & 15.94 & 0.12 & 1.80 & 0.32 & $<0.01$ & $<0.01$ & 0.01 & 0.02 & $<0.01$ & $<0.01$ & 0.11 & 0.57 & 0.89 \\
\hline & Blue layer & 0.6 & 3.5 & 2.7 & 58.3 & 1.22 & 0.33 & 0.06 & 14.03 & 15.91 & 0.11 & 1.77 & 0.43 & 0.08 & 0.02 & 0.01 & 0.02 & 0.41 & $<0.01$ & 0.08 & 0.43 & 0.88 \\
\hline \multirow{2}{*}{$\mathrm{VCR} 15$} & Red layer & 0.7 & 3.5 & 2.9 & 58.8 & 1.19 & 0.38 & 0.06 & 14.13 & 15.92 & 0.11 & 1.76 & 0.28 & $<0.01$ & 0.01 & 0.01 & 0.02 & $<0.01$ & 0.02 & 0.09 & 0.49 & 0.89 \\
\hline & Blue layer & 0.7 & 3.6 & 2.7 & 57.9 & 1.19 & 0.33 & 0.07 & 13.78 & 15.96 & 0.12 & 1.77 & 0.45 & 0.10 & 0.02 & 0.01 & 0.02 & 0.45 & $<0.01$ & 0.09 & 0.47 & 0.86 \\
\hline PNP05 & Colorless & 1.1 & 2.8 & 4.1 & 61.7 & 1.91 & 0.27 & 0.24 & 6.39 & 19.62 & 0.16 & 0.72 & 0.70 & n.d. & 0.03 & 0.01 & 0.02 & 0.04 & $<0.01$ & 0.07 & 0.003 & 0.33 \\
\hline PNP06 & Colorless & 1.2 & 0.52 & 0.5 & 67.4 & 0.22 & 0.31 & 0.28 & 19.37 & 8.64 & 0.02 & 0.12 & 0.18 & n.d. & $<0.01$ & 0.01 & 0.02 & 0.69 & $<0.04$ & $<0.03$ & $<0.16$ & 2.26 \\
\hline PNP07 & Colorless & 1.7 & 1.6 & 0.90 & 63.5 & 1.23 & 0.57 & 0.28 & 14.88 & 12.15 & 0.05 & 0.88 & 0.23 & n.d. & 0.01 & 0.05 & 0.05 & 0.49 & 0.06 & $<0.08$ & 0.22 & 1.22 \\
\hline PNP12 & Colorless & 2.0 & 2.8 & 5.3 & 59.0 & 1.73 & $<0.03$ & 0.45 & 5.29 & 19.63 & 0.28 & 0.78 & 0.91 & $<0.01$ & 0.02 & 0.01 & 0.03 & 0.03 & $<0.01$ & 0.08 & 0.27 & 0.27 \\
\hline \multirow[t]{2}{*}{ PNP16 } & Colorless & 1.1 & 3.2 & 4.9 & 59.2 & 1.96 & 0.19 & 0.18 & 6.72 & 19.88 & 0.28 & 0.89 & 1.01 & $<0.02$ & 0.01 & 0.03 & 0.02 & 0.03 & $<0.01$ & 0.1 & 0.37 & 0.34 \\
\hline & Red layer & 1.1 & 3.0 & 4.8 & 59.1 & 2.01 & $<0.04$ & 0.15 & 6.76 & 18.91 & 0.28 & 0.90 & 0.94 & $<0.03$ & $<0.02$ & 0.91 & $<0.03$ & $<0.01$ & $<0.01$ & $<0.03$ & 0.32 & 0.36 \\
\hline PNP17 & Colorless & 1.8 & 2.9 & 5.3 & 59.4 & 1.76 & $<0.02$ & 0.41 & 5.37 & 19.86 & 0.26 & 0.81 & 0.87 & $<0.01$ & $<0.01$ & $<0.002$ & 0.03 & 0.03 & $<0.01$ & 0.09 & 0.24 & 0.27 \\
\hline \multirow[t]{2}{*}{$\mathrm{CMOG} \mathrm{B}^{\mathrm{a}}$} & Reference & 17.00 & 1.03 & 4.36 & 62.27 & 0.82 & & & 1.00 & 8.56 & 0.09 & 0.25 & 0.34 & 0.05 & 0.01 & 2.66 & 0.19 & & & 0.02 & 0.12 & \\
\hline & Measured & 15.4 & 1.0 & 4.1 & 64.6 & 0.74 & & & 1.0 & 7.57 & 0.09 & 0.21 & 0.31 & 0.04 & 0.09 & 2.4 & 0.18 & & & $<0.02$ & 0.06 & \\
\hline \multirow[t]{2}{*}{ CMOG D $^{\mathrm{a}}$} & Reference & 1.20 & 3.94 & 5.30 & 55.46 & 3.93 & & & 11.3 & 14.8 & 0.38 & 0.55 & 0.52 & 0.02 & & 0.38 & 0.10 & & & 0.06 & 0.51 & \\
\hline & Measured & 1.4 & 3.7 & 4.9 & 57.5 & 3.9 & & & 10.2 & 12.9 & 0.35 & 0.42 & 0.45 & $<0.03$ & & 0.29 & 0.10 & & & $<0.03$ & 0.27 & \\
\hline
\end{tabular}

${ }^{\mathrm{a}}$ Reference values taken from Brill (1999).

n.d., non-detected; CMOG B, Corning Museum of Glass B; CMOG D, Corning Museum of Glass D. 


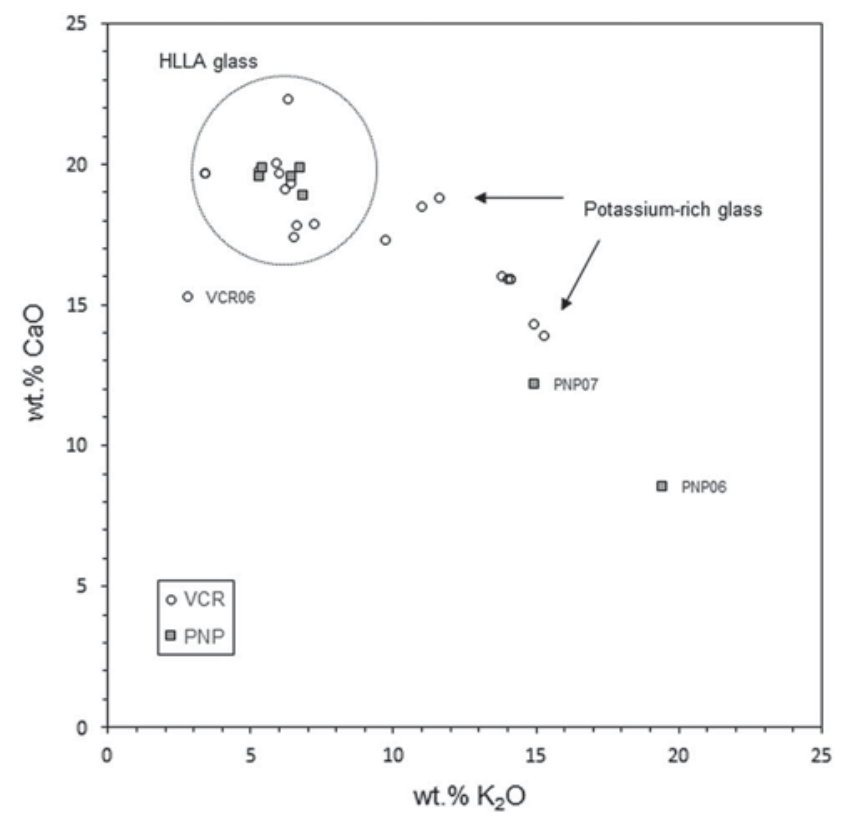

Figure 3. $\mathrm{K}_{2} \mathrm{O}$ versus $\mathrm{CaO}$ biplot for the analysed stained-glass fragments. HLLA, high lime-low alkali composition; VCR, Vitrocentre Romont; PNP, Pena National Palace.

The second group shows $\mathrm{K}_{2} \mathrm{O}$ concentrations ranging between 9.8 and $15.2 \mathrm{wt} \%, \mathrm{CaO}$ ranges from $12.1 \mathrm{wt} \%$ up to $18.8 \mathrm{wt} \%$, and $\mathrm{Na}_{2} \mathrm{O}$ concentration between 0.42 and $1.9 \mathrm{wt} \%$. The $\mathrm{MgO}$ concentration varies between 1.6 and $3.6 \mathrm{wt} \%$, $\mathrm{P}_{2} \mathrm{O}_{5}$ is among 1.2 and $1.5 \mathrm{wt} \%$, and $\mathrm{Al}_{2} \mathrm{O}_{3}$ between 0.92 and $3.9 \mathrm{wt} \%$. This group includes all the colored glass as well as the colorless samples VCR03 and PNP07.

The concentrations of the glass colorants $(\mathrm{MnO}, \mathrm{CoO}$, and $\mathrm{CuO}$ ) vary between 0.5 and $1.8 \mathrm{wt} \%$ for HLLA glass and between 0.9 and $2.9 \mathrm{wt} \%$ for the potassium-rich glass.

Regarding the flashed glasses, the different layers in each sample always have a similar glass composition. In samples VCR07 and VCR08 both the colorless base glass and the red flash layer are of HLLA glass type. In samples VCR09, VCR14, and VCR15 (red and blue flashed glass), both layers are made of a potassium-rich glass (group 2); the layers of the purple flashed glass (VCR10) also have a potassium-rich composition.

All the flashed glass samples show a clear and sharp interface (Fig. 4) between the colorless and red glass. Similar characteristics have been observed on so-called "type B-3" red glass by (Kunicki-Goldfinger et al., 2014). They apparently correspond with production technology typical for 16 th century stained glass.

\section{Silica Sources}

The majority of the stained-glass samples (with exception of samples PNP06 and PNP07) have a medium to high alumina content, indicating the use of a quartz sand containing some alumina (Lima et al., 2012).

The plot presented in Figure 5 shows the $\mathrm{Al}_{2} \mathrm{O}_{3} / \mathrm{SiO}_{2}$ versus $\mathrm{TiO}_{2} / \mathrm{SiO}_{2}$ ratios, two important elements associated with identifying the silica source. All samples fall on a correlation line, suggesting that sand from the same source

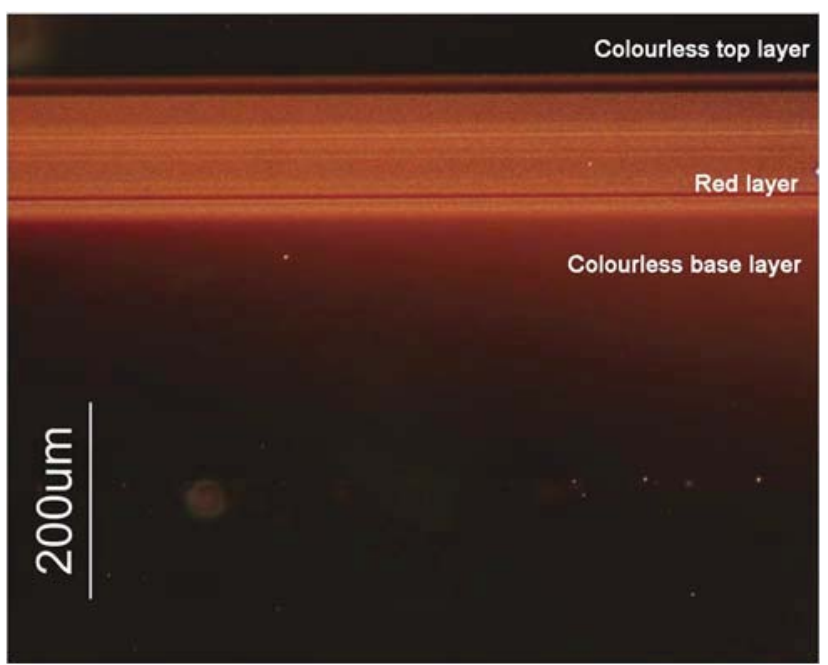

Figure 4. Optical microscope image of sample VCR07 showing a red glass layer between two layers of colorless glass.

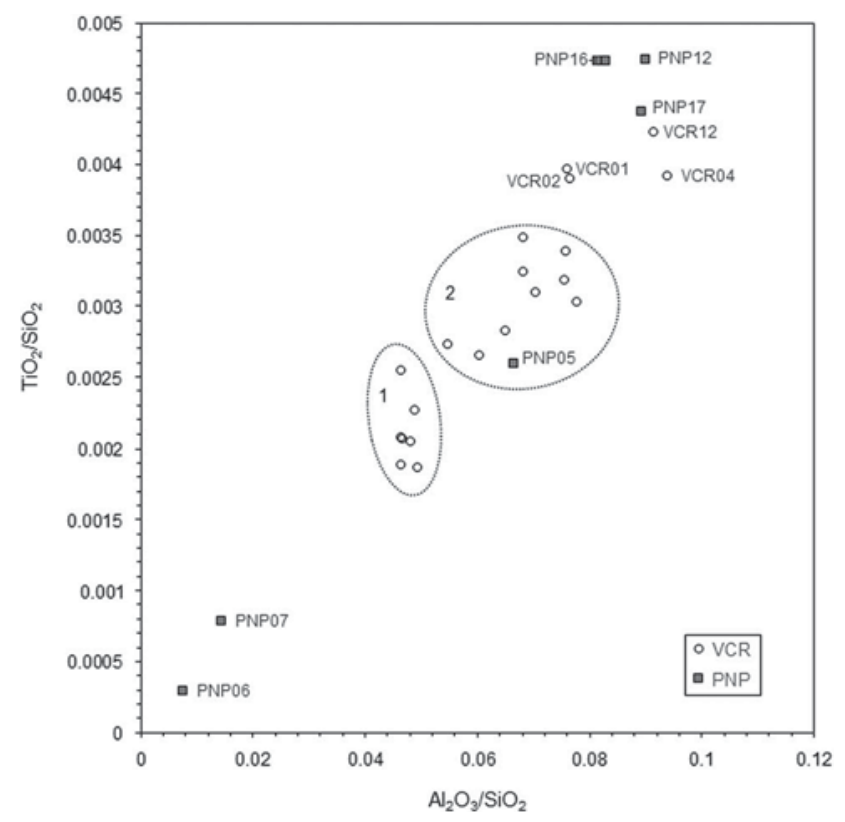

Figure 5. $\mathrm{Al}_{2} \mathrm{O}_{3} / \mathrm{SiO}_{2}$ versus $\mathrm{TiO}_{2} / \mathrm{SiO}_{2}$ plot, showing the relationship of trace elements associated with the silica sources. In the case of the colored glass, the coloring elements were identified and omitted from the data set and the glass compositions normalized. VCR, Vitrocentre Romont; PNP, Pena National Palace.

region was used to produce the glass. Most of the fragments from the VCR set, as well as one sample from the Portuguese collection (PNP05) cluster together in two groups (Fig. 5), each of which shows close-ranging $\mathrm{Al}_{2} \mathrm{O}_{3} / \mathrm{SiO}_{2}$ and $\mathrm{TiO}_{2} / \mathrm{SiO}_{2}$ ratios, which might point to the use of sand from a very similar sand source in each case. The chemical similarity of the samples in group one, which includes VCR03, VCR11, VCR13, VCR14, and VCR15, could even be an indication that the glass was produced by the same glassworks.

The stained glass from the PNP set (except for PNP05) seems to have been produced from different sand sources that come from the same (geological) region. The low $\mathrm{TiO}_{2}$ 
and $\mathrm{Al}_{2} \mathrm{O}_{3}$ contents of the colorless glass of PNP06 and PNP07 are consistent with those of Venetian glass, which might be an indication of the employment of a very pure quartz sand or crushed quartz pebbles for the production of this glass (Verità, 2013).

It is interesting that samples PNP05 and PNP17, which are known to belong to two panels from the same church in Kriens near Luzern (PNP2808 and PNP2820), do not fall in the same group. It seems that glass sheets from different glassworks (in the same region) or different production periods were used to make these panels.

The titanium and iron concentrations in the glass are related to heavy minerals present in the sand (Cagno et al., 2012). As in the previous plot, the majority of the samples show a strong positive correlation between titanium and iron (Fig. 6) suggesting that (geologically) similar sands were used to produce the glass. The close grouping of samples VCR03, VCR11, VCR13, VCR14, and VCR15 (see Fig. 6) again suggest that the glass was produced in the same glassworks; the red glass layers in samples VCR14 and VCR15 are slightly lower in iron than the blue glass layers suggesting that two batches of colored glass, one red and one blue, were used for the production of purple flashed glass.

\section{Alkali Sources}

As above, the glass from both sets can be divided into two glass types: HLLA and a potassium-rich glass (cf. Fig. 3). For all except sample $\mathrm{PNP} 06$, the $\mathrm{K}_{2} \mathrm{O} / \mathrm{CaO}$ ratios suggest the use of wood ash as a fluxing agent (Stern \& Gerber, 2004).

Figure 7 shows the $\mathrm{P}_{2} \mathrm{O}_{5}$ content versus $\mathrm{CaO} / \mathrm{K}_{2} \mathrm{O}$ ratio in order to differentiate the types of flux employed, that is, to distinguish weather untreated wood ash or potash-a leached ash-was used to produce the glass (Stern \& Gerber, 2009).

All except one sample (PNP06) fall into two glass groups that were both made with unprocessed wood ash as a flux: The samples in cluster $a$ have $\mathrm{P}_{2} \mathrm{O}_{5}$ concentrations ranging between 1.2 and $1.5 \mathrm{wt} \%, \mathrm{CaO}$ contents from 12 to almost $19 \mathrm{wt} \%$, and $\mathrm{a} \mathrm{K}_{2} \mathrm{O} / \mathrm{CaO}$ ratio between 0.6 and 1.2 ; their compositions are similar to a glass type described as K-Ca-3 by Stern \& Gerber (2004). These authors suggest that glass of this composition was possibly made using a mixture of limestone and wood ash. The majority of the potassium-rich samples from the VCR set and sample PNP07 fall within this cluster.

Cluster $b$ comprises the majority of the HLLA glass samples. The samples in cluster $b$ have higher phosphorous levels $\left(1.8-2.2 \mathrm{wt} \% \mathrm{P}_{2} \mathrm{O}_{5}\right)$ and a lower $\mathrm{K}_{2} \mathrm{O} / \mathrm{CaO}$ ratio $(<0.4)$ than those of cluster $a$. Their composition is comparable with a glass type called $\mathrm{K}-\mathrm{Ca}-2$ by some authors (Barrera \& Velde, 1989; Stern \& Gerber, 2004) and presumed to have been made from sand and untreated wood ash, without addition of limestone. It is not possible to distinguish the type of wood ash used. One sample (PNP06) has a $\mathrm{K}_{2} \mathrm{O} / \mathrm{CaO}$ ratio $>2$ and a very low-phosphorous content, which suggests the use of potash, that is leached wood ash, or possibly fern ash (Stern \& Gerber, 2009).

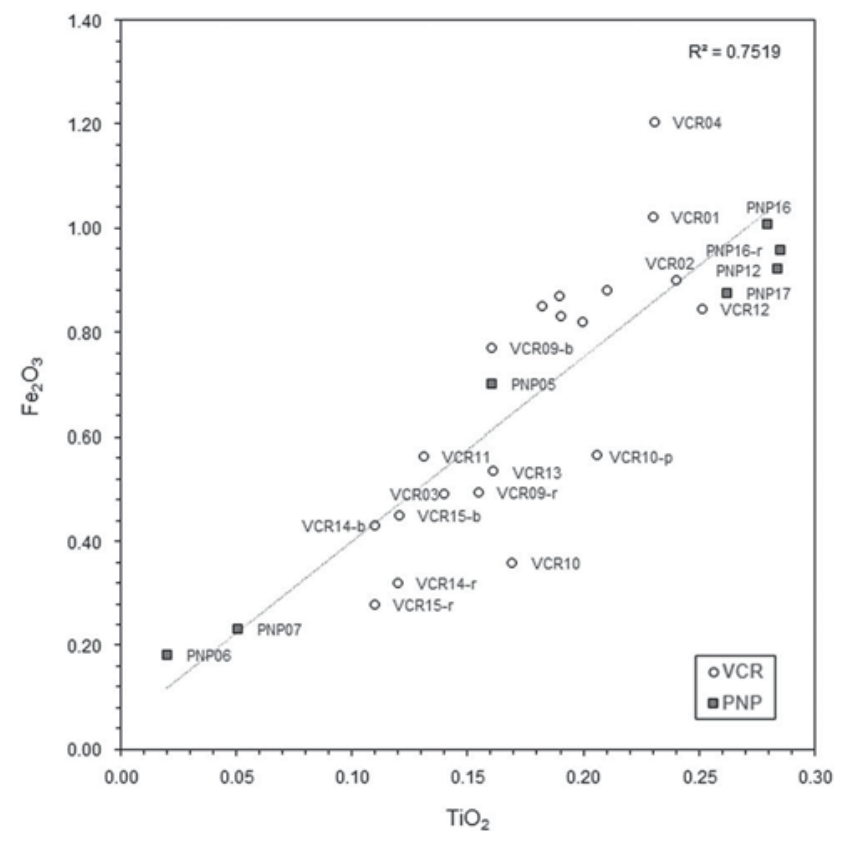

Figure 6. $\mathrm{Fe}_{2} \mathrm{O}_{3}$ versus $\mathrm{TiO}_{2}$ biplot for the stained-glass samples analysed. The flashed stained-glass sample are identified as follows: r: red, b: blue; p: purple; VCR, Vitrocentre Romont; PNP, Pena National Palace.

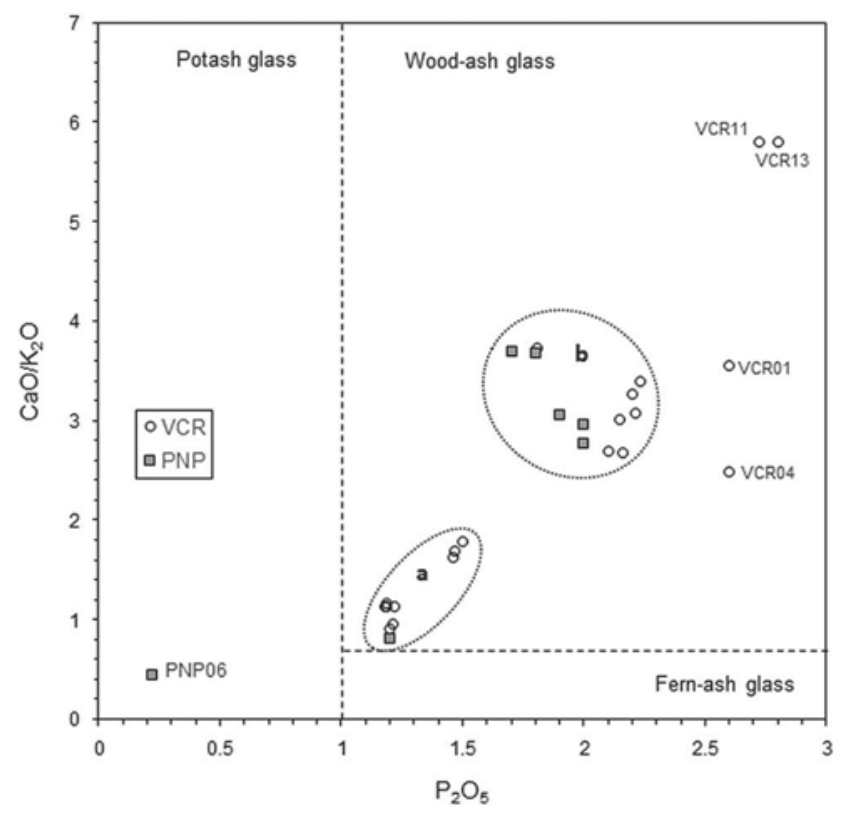

Figure 7. $\mathrm{P}_{2} \mathrm{O}_{5}$ versus $\mathrm{CaO} / \mathrm{K}_{2} \mathrm{O}$ plot, presenting the relation of the elements associated with the type of ash employed. VCR, Vitrocentre Romont; PNP, Pena National Palace.

Provenance of the Glass

Looking at the silica as well as at the alkali sources, we observe that glass samples with similar ash compositions seem to have been made using sand from the same source. For example, samples VCR03, VCR14, and VCR15 from cluster $a$ belong to group 1 in Figure 5. PNP05, VCR05, 
VCR07, and VCR08 from cluster $b$ are part of group 2 in Figure 5. Samples PNP12 and PNP17 from cluster $b$ were probably also made using a similar sand source (cf. Fig. 5). The combined results suggest that the glass used to make the panels came from several glassworks that were active in the same region during the period in question. These glass factories employed similar silica sources and were mostly using wood ash as the fluxing agent. The results moreover, show that the colorless and the red flashed glass were produced from the same or very similar raw materials that came from the same source region. The data seems to contradict the hypothesis of different origins for the colorless and the colored glass (Historical Background and Aim of the Study section). Further analyses providing trace and ultra-trace element data will, however, be necessary to verify these results.

\section{Glass Paints}

The glass paints, namely the blue enamel and the grisaille, from some of the stained-glass fragments of both sets were analysed by SEM/EDS using BSE images and by $\mu$-PIXE in order to study the morphology and the composition of the paint layers. The results of the chemical analysis are based on the mean average of three measurements per measurement spot.

\section{Blue Enamel}

Figure 8 shows representative examples of the analysed blue enamels. The enamel layers are heterogeneous and include various glassy phases, bubbles, and inclusions that are rich in silicon and aluminum; the inclusions are probably quartz and feldspar grains. The thickness of the enamel layer ranges between approximately 30 and $80 \mu \mathrm{m}$; the thicknesses can vary within the same layer. The interface between the enamel and the base glass is well defined for all the samples, with exception of sample VCR03. This sample stands out, because it has a more diffuse interface and a more homogeneous enamel layer (cf. Fig. 8b).

Small white spots are present throughout the enamel and, in some cases, they follow the same patterns of some of the glassy phases, as can be seen on the enamel from sample VCR03 (cf. Fig. 8b). White angular inclusions of a size similar to the quartz and feldspar grains were observed in some samples (cf. Fig. 8c). EDS analyses of these inclusions revealed high levels of arsenic and nickel (Fig. 9).

Some of the enamel layers show micro cracks (cf. Fig. 8a). They either run roughly parallel to the surface or in a diagonal direction. Sometimes they continue into the base glass. The enamels analysed by Van der Snickt et al. (2006) show similar characteristics. In some cases these cracks seem to connect the gas bubbles and sometimes continue into the glass substrate (Fig. 10).

EDS and $\mu$-PIXE analysis show that all the blue enamels belong to the Co-As-Ni-Bi group identified by Gratuze et al. (1992, 1996). The cobalt ore used to produce the enamel probably comes from the mining district of Schneeberg, Germany, which was exploited between the 16th and 18th centuries (Kunckel, 1752). The blue enamels of the VCR set have $\mathrm{CoO}$ concentrations ranging between 0.33 and $3.49 \mathrm{wt}$ $\%$, and low to intermediate contents of $\mathrm{PbO}$ varying between 0.18 and $5.1 \mathrm{wt} \%$. The blue enamels from the PNP set show $\mathrm{CoO}$ concentrations between 2.02 and $3.2 \mathrm{wt} \%$; $\mathrm{PbO}$ concentrations in these samples are below the detection limit. The contents of nickel and arsenic (as well as bismuth), which are associated with the cobalt ore, are very similar in the samples from both sets, with exception of samples VCR03 and PNP17 (Fig. 11). However, these differences probably reflect natural variations of $\mathrm{NiO} / \mathrm{CoO}$ that can occur on the cobalt ore (Gratuze et al., 1992).

The blue enamels of two samples (VCR02 and VCR05) stand out for their relatively high lead content. Lead is also related to the cobalt ore. These two enamels also have similar aluminum, titanium, and iron concentrations, elements which are associated with the silica used for the production of the enamel. It seems likely that the blue enamel of these two samples was made using the same recipe. Regarding the other samples analysed, the variable composition of the enamels seems to suggest the use of slightly different enamel recipes, but using cobalt ore from the same provenance as a colorant.

\section{Grisaille}

Results of $\mu$-PIXE analyses on grisaille paints from samples of both sets show that it is composed of a lead-rich silicate matrix containing iron and copper components as pigments. One of the samples of the VCR set (VCR05) contains
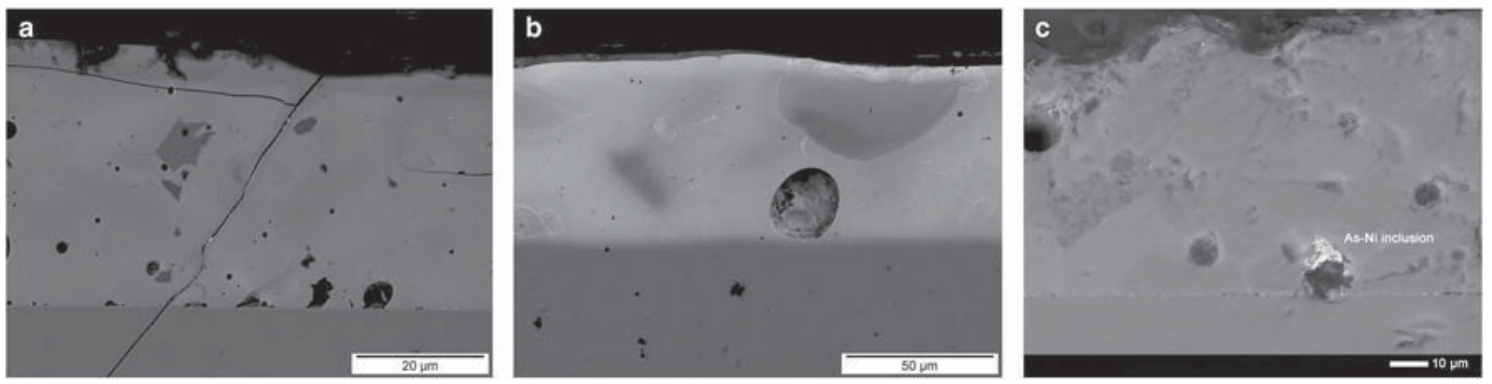

Figure 8. Scanning electron microscopy/backscattered electron image mode images of blue enamels (a) VCR02, (b) VCR03, and (c) PNP12. VCR, Vitrocentre Romont; PNP, Pena National Palace. 

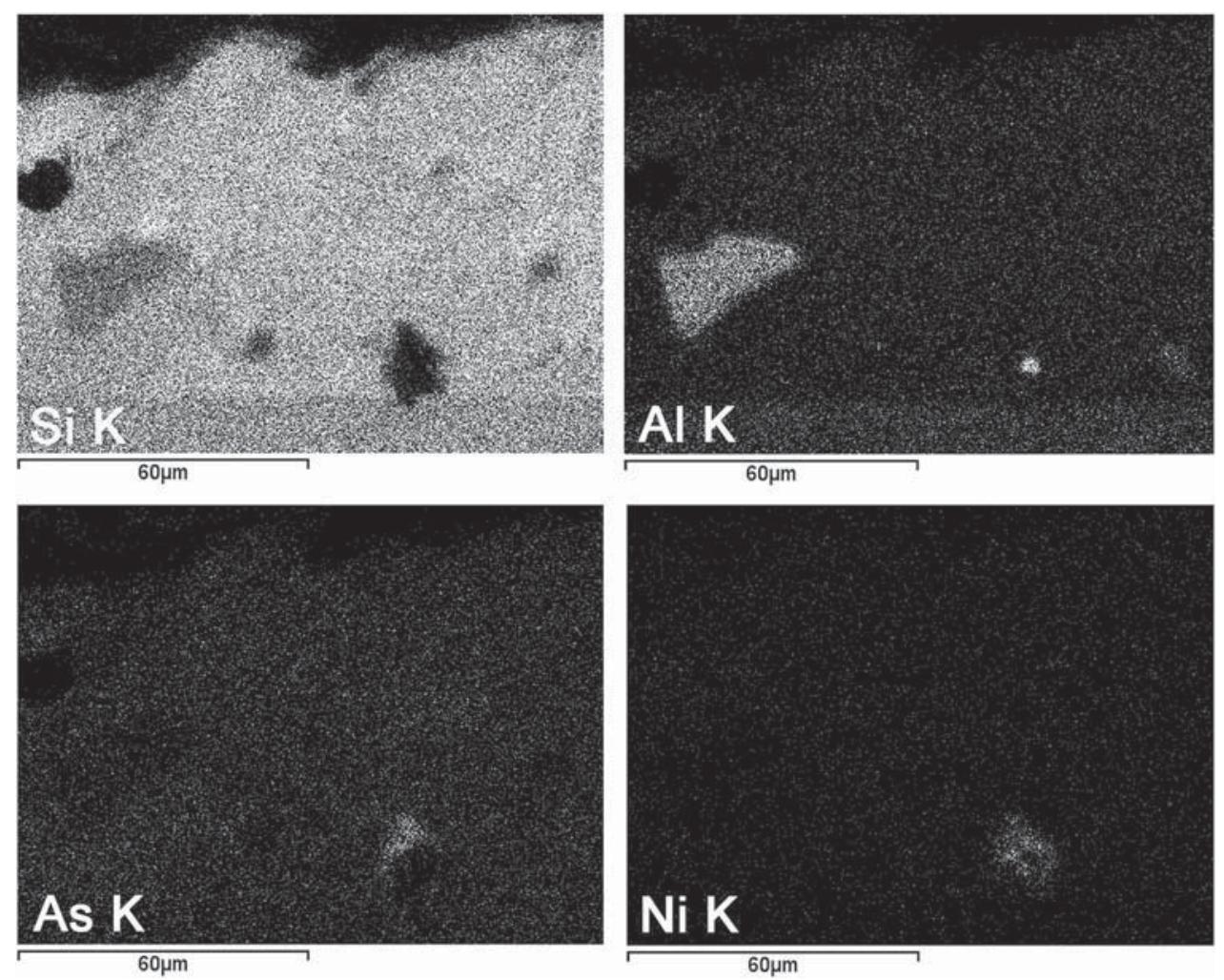

Figure 9. Scanning electron microscopy-electron-dispersive X-ray spectroscopy map of sample PNP12. A glassy matrix with aluminum-rich inclusions can be observed as well as an area enriched in arsenic and nickel.

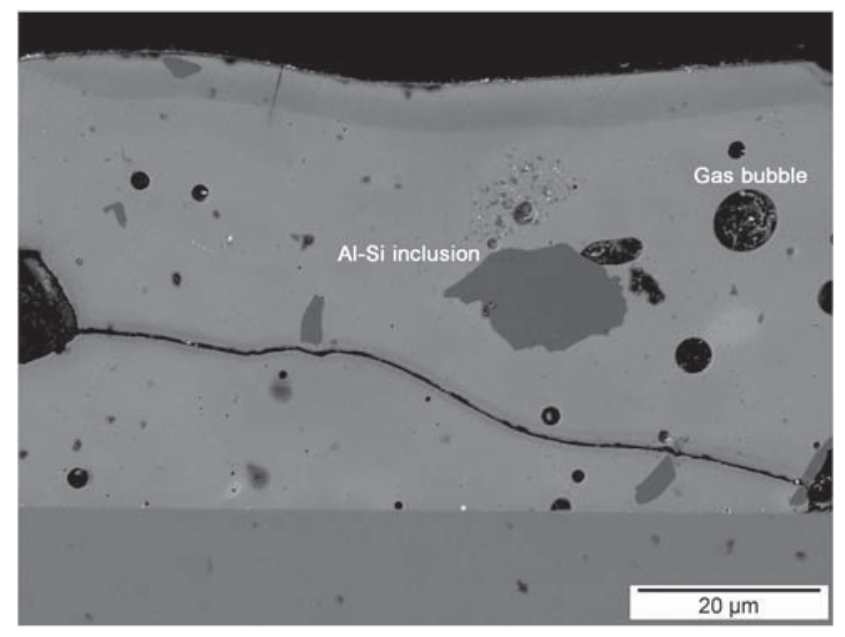

Figure 10. Scanning electron microscopy/backscattered electron image mode image of sample VCR0 showing air bubbles and inclusions in the blue enamel layer. The micro crack running diagonally to the surface connects two gas bubbles.

17.3 wt $\% \mathrm{Fe}_{2} \mathrm{O}_{3}, 4.7 \mathrm{wt} \% \mathrm{CuO}$, and $31.2 \mathrm{wt} \% \mathrm{PbO}$. Similar results are found for grisaille paints from the 16th century (Vilarigues \& Da Silva, 2004; Carmona et al., 2006; Pradell et al., 2016). Sample VCR12 has inverted iron and copper concentrations (see Table 4, 6.4 wt $\% \mathrm{Fe}_{2} \mathrm{O}_{3}, 18.6$ wt $\% \mathrm{CuO}$ ); the lead concentration is similar to that of VCR05 (43.1 wt\% $\mathrm{PbO})$. The amount of flux relative to the pigment $\left(\mathrm{PbO} /\left(\mathrm{Fe}_{2} \mathrm{O}_{3}+\mathrm{CuO}+\mathrm{PbO}\right)\right)$ is $59 \mathrm{wt} \%$ for sample VCR05

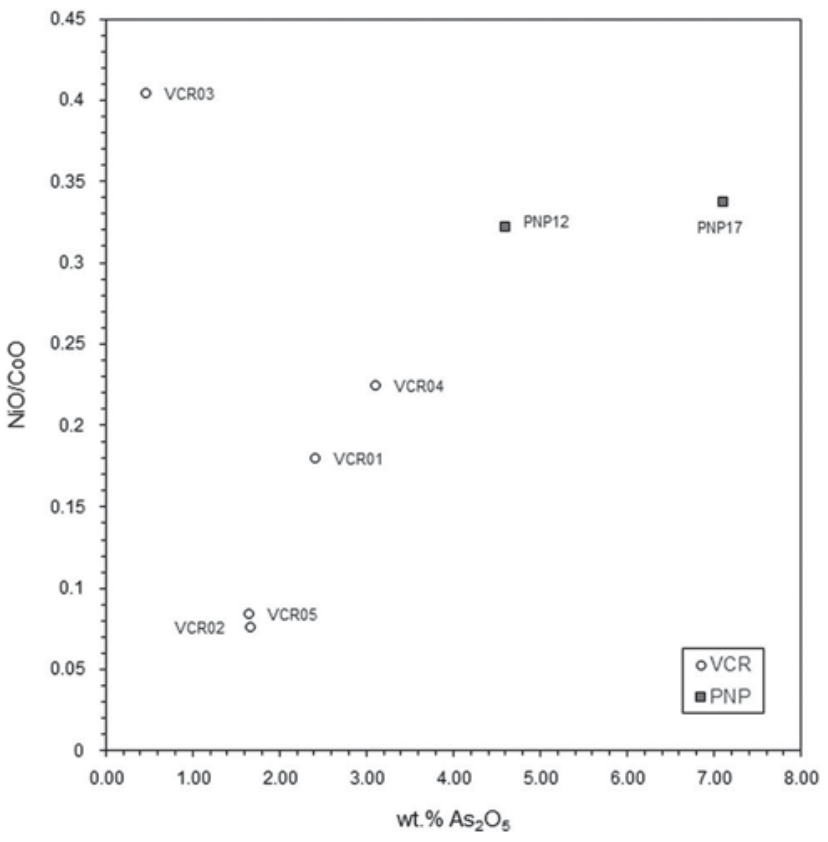

Figure 11. $\mathrm{As}_{2} \mathrm{O}_{5}$ versus $\mathrm{NiO} / \mathrm{CoO}$ biplot for the blue enamel samples analysed. VCR, Vitrocentre Romont; PNP, Pena National Palace.

and $63 \mathrm{wt} \%$ for sample VCR12; these results are in agreement with the ones obtained for grisaille paints dating to the 17th century (Pradell et al., 2016). When analysed, the grisaille on samples from the PNP set (Table 4) show slightly lower flux to pigment ratios: the grisaille on PNP05 has a 
م્م| ڤొ

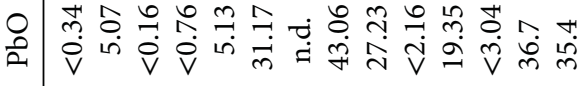

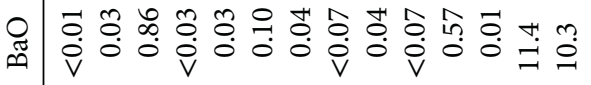
ڤ

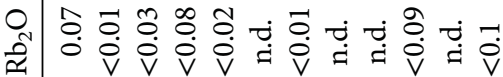

ก $06 \%$ ○

乐

虽

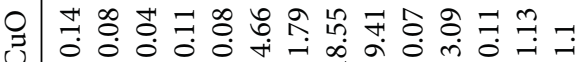

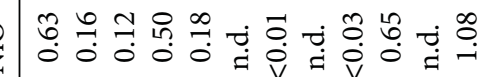

O

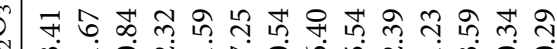

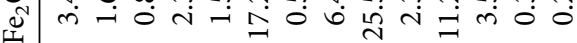

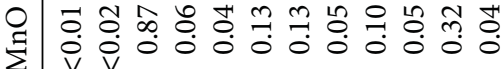

ํ=1

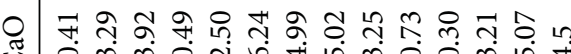

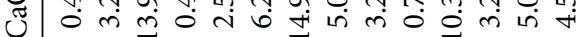

○

v $₫ \infty$ b

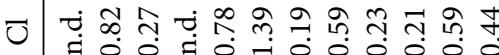

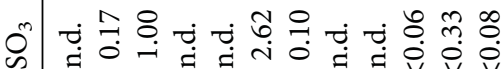

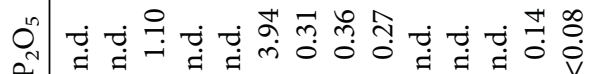

ก $\frac{\pi}{2} m \infty$ n

क

ஓ্సু

ヘิ

胥

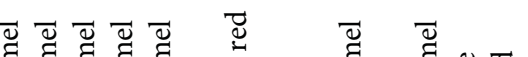

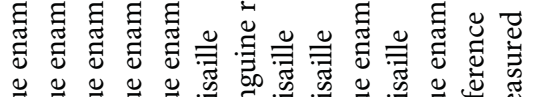

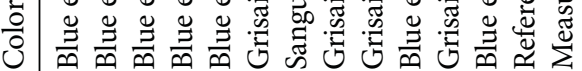

ratio of $44 \mathrm{wt} \%$ and $\mathrm{PNP} 17$ has a ratio of $57 \mathrm{wt} \%$. This latter sample also contains $2.6 \mathrm{wt} \% \mathrm{Ag}_{2} \mathrm{O}$, which is due to the fact that this sample is also painted with silver stain on the backside of the stained glass fragment.

SEM/EDS analysis of the grisaille layers revealed varying thicknesses for the grisaille layers: in sample VCR05 its thickness ranges between 20 and $50 \mu \mathrm{m}$, in sample PNP06 it varies between 2 and $10 \mu \mathrm{m}$ (Fig. 12). The grisaille layer in sample VCR05 is more porous and heterogeneous than that of PNP06; but both samples contain iron grains of various sizes surrounded by a leadrich matrix (cf. Fig. 10a).

The interface between the grisaille and the base glass is smooth in both samples, suggesting that the lead diffused into the glass well and that there is a good adherence between the paint layer and the glass. This is evidence of the high quality of the grisaille painting, which was properly fused in during the firing process.

EDS maps of the grisaille layers in samples VCR05 and PNP06 reveal the even distribution of the iron and copper pigment particles. The lead is finely dispersed in the matrix (Fig. 13). The production process of the grisaille explains this morphology. The grisaille paint layers are fixed to the glass at firing temperatures of around $600-750^{\circ} \mathrm{C}$. At these temperatures the lead compound melts completely whereas copper and iron pigments, which have higher melting temperatures, remain solid (Vilarigues \& Da Silva, 2004).

\section{CONCLUSIONS}

This paper presents the results of a study on Swiss stained glass produced in the early modern period. The data presented here is a first step toward a better understanding of the provenance and production technology of stained-glass panels, so-called Wappenscheiben, which were produced for the "Swiss" market between the 16th and 18th century and have found their way into many museum collections all over the world.

The analytical techniques employed to study the compositions of the base glass and glass paints of stained-glass panels from two different collections in Portugal and Switzerland proved successful in characterizing the materials and identifying the technology used in their production. The analysis also enabled initial suggestions about the origin of the raw materials for the glass and the enamel paint to be made: both the colored and uncolored sheet glass was made using sand from a similar source region and some of the glass may have been made in the same glassworks. Unprocessed wood ash was used as flux in all but one case. Different recipes seem to have been used to make the blue enamels. However, the cobalt ore used as a coloring agent in all of the blue enamels is likely to have come from the same mining district in Schneeberg, Germany.

Further analytical studies, extending this preliminary database and also including trace and ultra-trace elemental data, are necessary to get more detailed information on the 

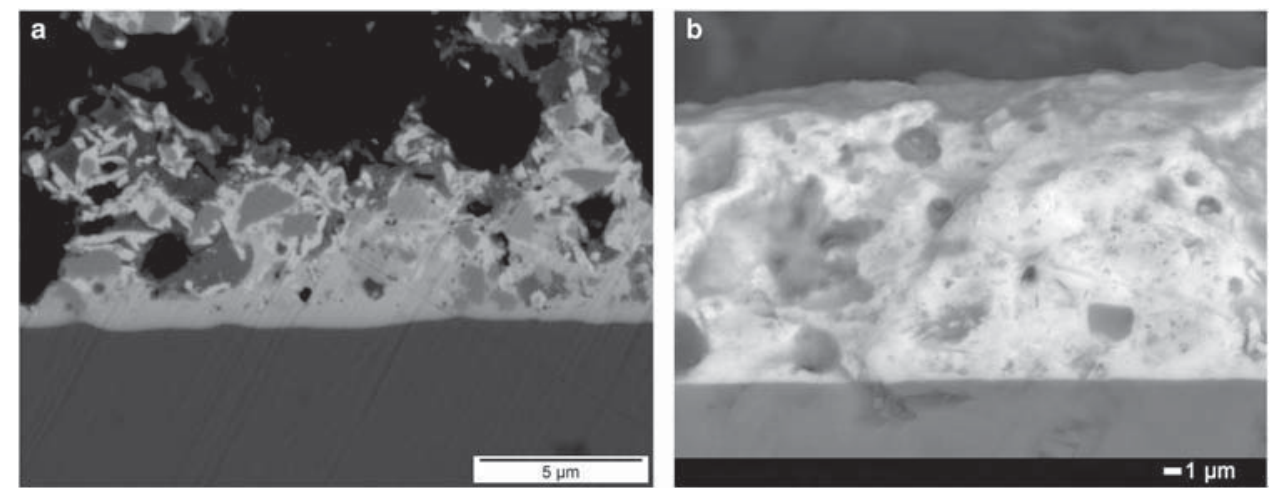

Figure 12. Scanning electron microscopy/backscattered electron image mode images of grisaille layer in samples (a) VCR05 and (b) PNP06.
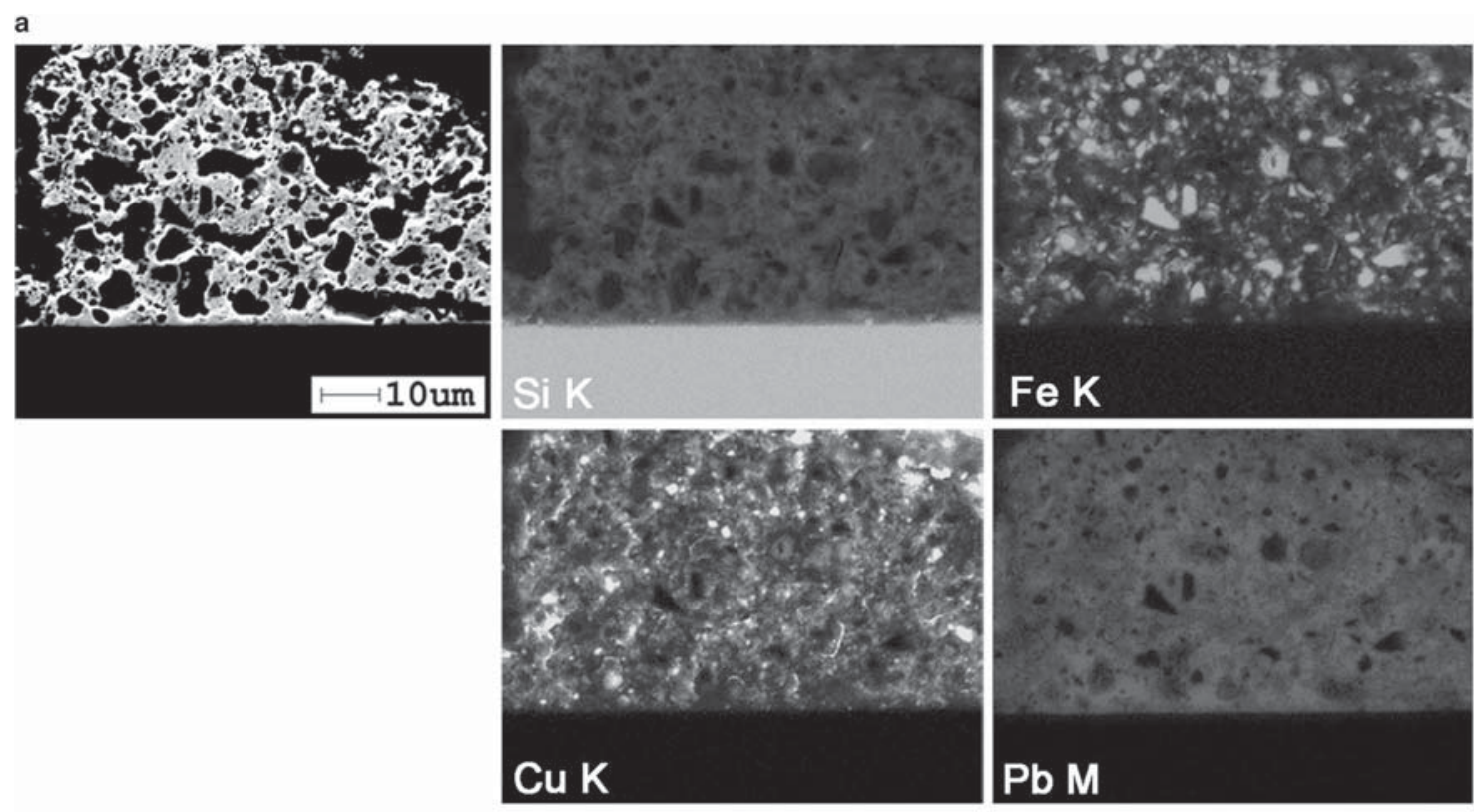

b
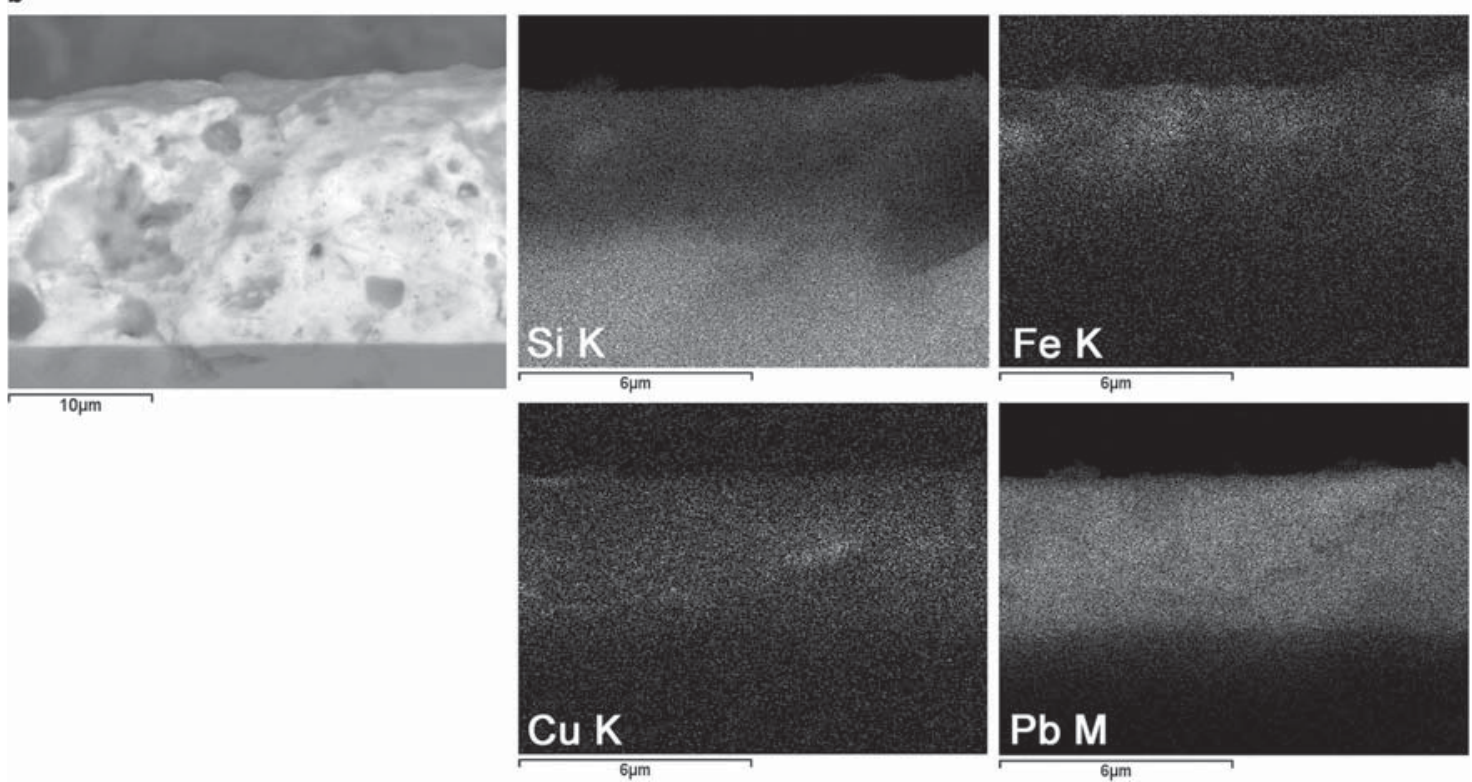

Figure 13. Scanning electron microscopy/electron-dispersive X-ray spectroscopy maps for the grisaille layers of samples (a) VCR05 and (b) PNP06. 
origins of glass production, as well as on the trade and transfer of materials and the technology used to produce this particular kind of stained glass. Only a large database will allow the picture to be refined and enable the necessary comparisons to be made. It might also allow specific questions to be resolved, for example by identifying the provenance and trade of colored sheet glass used to make "Wappenscheiben" in the early modern period.

\section{ACKNOWLEDGMENTS}

A.M., M.V., and L.C.A. thank the Fundação para a Ciência e Tecnologia (FCT) for supporting their research (grant no. SFRH/BD/78882/2011, project numbers PTDC/EPH-PAT/ 3579/2012, UID/EAT/00729/2013, and UID/Multi/04349/ 2013). The authors are also greatly indebted to Uta Bergmann and Rolf Hasler for their comments to this paper, to Parques de Sintra, Monte da Lua, SA, the director of Pena National Palace, António Nunes Pereira, as well as the Vitromusée Romont.

\section{REFERENCES}

Barrera, J. \& Velde, B. (1989). A study of French medieval glass composition. Archéologie Médiévale XIX, 81-127.

Bellot-Gurlet, L., Poupeau, G., Salomon, J., Calligaro, T., Moignard, B., Dran, J.C., Barrat, J.A. \& Pichon, L. (2005). Obsidian provenance studies in archaeology: A comparison between PIXE, ICP-AES and ICP-MS. Nucl Instrum Meth B 240, 583-588.

Bergmann, U. (2014). Die Stellung und Bedeutung der Freiburger Glasmalereiproduktion/La place de la production fribourgeoise dans l'art du vitrail. In Die Freiburger Glasmalerei des 16. bis 18. Jahrhunderts/Le Vitrail Fribourgeois du XVIe au XVIIIe siècle, Corpus Vitrearum Schweiz (Ed.), pp. 178-185. Bern: Peter Lang.

Bergmann, U. (2016). Das Zürcher Handwerksbuch. Einblick in die Handwerksgeschichte der Zürcher Glasmaler und Glaser. In "Licht(t)räume". Festschrift zum 65. Geburtstag von Brigitte Kurmann-Schwarz zum 65. Geburtstag, Georgi, K., von OrelliMesserli, B., Scheiwiller-Lorber E. \& Schiffhauer A. (Eds.), pp. 18-26. Petersberg: Imhof.

Bergmann, U., Hasler, R., Jolidon, Y., Kaiser, A., Kurmann-Schwarz, B. \& TrÜMpler, S. (2006). Stained Glass, An Introduction Based on Examples from the Vitromusée Romont and the Surronding Region. Villars-sur-Glâne: Imprimerie MTL SA.

Boesch, P. (1955). Die Schweizer Glasmalerei. Basel: Birkhäuser Verlag Basel.

BriLl, R. H. (1999). Chemical Analysis of Early Glasses. Corning, NY: The Corning Museum of Glass. pp. 544.

Cagno, S., Brondi Badano, M., Mathis, F., Strivay, D. \& Janssens, K. (2012). Study of medieval glass fragments from Savona (Italy) and their relation with the glass produced in Altare. J Archaeol Sci 39, 2191-2197.

Campbell, J.L., Boyd, N.I., Grassi, N., Bonnick, P. \& Maxwell, J.A. (2010). The Guelph PIXE software package IV. Nucl Instrum Meth B 268, 3356-3363.

Carmona, N., Villegas, M.A. \& Navarro, J.M.F. (2006). Study of glasses with grisailles from historic stained glass windows of the cathedral of León (Spain). Appl Surf Sci 252, 5936-5945.
CAVINESS, M. H. (2010). Collectors' Choice: Kabinettscheiben as Singles and Series. In Les panneaux de vitrail isolés; Die Einzelscheibe; The single stained-glass panel - Actes du XXIVe Colloque International du Corpus Vitrearum Zurich 2008, Sauterel, V. \& Trümpler, S. (Eds.) pp. 191-204. Berne: Peter Lang.

Coutinho, I., Medici, T., Alves, L.C., Gratuze, B. \& Vilarigues, M. (2016). Provenance studies on façon-de-Venise glass excavated in Portugal. J Archaeol Sci Rep 7, 437-448.

Gerber, C. (2010). Court, Pâturage de l' Envers: une verrerie forestière jurassienne du début du 18e siècle. Volume 1: Les vestiges. Bern: Service archéologique du Canton de Berne.

Gerber, Y. \& SteRn, W. (2012). Archäometrische Analysen und Gläser. In Court, Pâturage de l'Envers: une verrerie forestière juranienne $d u$ début du 18e siècle. Volume 2: des matières premières aux productions: approches historiques, techniques et archéométriques, Gerber, C., Gerber, Y., Stern, W., Kaiser, L. \& Eramo, G. (Eds.), pp. 95-162. Bern: Service archéologique du Canton de Berne.

Giesicke, B. \& Ruoss, M. (2000). In honor of friendship: Function, meaning and iconography in civic stained-glass donations in Switzerland and Southern Germany. In Painting on Light. Drawings and Stained Glass in the Age of Dürer and Holbein, Butts, B., Hendrix L. \& Wolf, S.C. (Eds.), pp. 43-55. Los Angeles: The J. Paul Getty Trust.

Gratuze, B., Soulier, I., Blet, M. \& Vallauri, L. (1996). De l'origine du cobalt: du verre à la céramique. Revue d'Archéométrie 20, 77-94.

Gratuze, B., Soulier, I., Barrandon, J.-N. \& Roy, D. (1992). De l'origine du cobalt dans les verres. Revue d'Archéométrie 16, 97-108.

Grime, G.W. \& Dawson, M. (1995). Recent developments in data acquisition and processing on the Oxford scanning proton microprobe. Nucl Instrum Meth B 104, 107-113.

HasLer, R. (2010). Die Schaffhauser Glasmalerei des 16. bis 18. Jahrhunderts. Bern: Peter Lang.

Hasler, R. \& TrümpleR, S. (1998). Le vitrail suisse aux XVIe et XVIIe siècles. In L'art du peintre-verrier, Gatouillat, F. \& Leproux, G. (Eds.), pp. 31-33. Bourges: Le Parvis des Métiers.

JANSSENs, K. (2013). Electron microscopy. In Modern Methods for Analysing Archaeological and Historical Glass, Janssens, K. (Ed.), pp. 129-154. West Sussex: John Wiley \& Sons, Ltd.

KunCKel, J. (1752). Art de la verrerie. In Art de la verreri, de Neri, Merret et Kunckel. Paris: Chez Durand et chez Pissot.

Kunicki-Goldfinger, J.J., Freestone, I.C., McDonald, I., Нobot, J.A., Gilderdale-SCOtT, H. \& Ayers, T. (2014). Technology, production and chronology of red window glass in the medieval period Rediscovery of a lost technology. J Archaeol Sci 41, 89-105.

Lehmann, H. (1941). Geschichte der Luzerner Glasmalerei von den Anfängen bis zu Beginn des 18. Jahrhunderts. Luzern: Keller \& Co.

Lima, A., Medici, T., Pires de Matos, A. \& VerttÀ, M. (2012). Chemical analysis of 17th century Millefiori glasses excavated in the Monastery of Sta. Clara-a-Velha, Portugal: Comparison with Venetian and façon-de-Venise production. J Archaeol Sci 39, 1238-1248.

Martinho, B. \& Vilarigues, M. (2011). A colecção / The collection. In Vitrais e Vidros, um gosto de D. Fernando II/Stained Glass and Glass Objects, Ferdinand II's passion, Martins, A.O. (Ed.), pp. 17-25. Monte da Lua, S.A.: Parques de Sintra.

Pradell, T., Molina, G., Murcia, S., Ibáñez, R., Liu, C., Molera, J. \& SHORTLAND, A.J. (2016). Materials, techniques, and conservation of historic stained glass "grisailles". Int J Appl Glass Sci 7, 41-58.

Schalm, O., Janssens, K., Wouters, H. \& Caluwé, D. (2007). Composition of 12-18th century window glass in Belgium: Non-figurative windows in secular buildings and stained-glass windows in religious buildings. Spectrochim Acta B 62, 663-668. 
SCHNeIDER, J. (1971). Glasgemälde. Katalog der Sammlung des Schwezerischen Landesmuseums Zürich. Stäfa: Verlag Th. Gut \& Co. Schneider, J. (1978). Glasgemälde: Neuerwerbungen 1978. JberZürich 87, 76-80.

Šmit, Ž., Janssens, K., Bulska, E., Wagner, B., Kos, M. \& Lazar, I. (2005). Trace element fingerprinting of façon-de-Venise glass. Nucl Instrum Meth B 239, 94-99.

Stern, W.B. \& Gerber, Y. (2004). Potassium-calcium glass: New data and experiments. Archaeometry 46, 137-156.

Stern, W. \& Gerber, Y. (2009). Ancient potassium-calcium glass and its raw materials (wood-ash, fern-ash, potash) in Central Europe. Mitt Naturf Ges 11, 107-122.
VAn der Snickt, G., Schalm, O., Caen, J., Janssens, K. \& Schreiner, M. (2006). Blue enamel on sixteenth and seventeenth-century window glass. Stud Conser 51, 212-222.

VeritȦ, M. (2013). Venetian Soda Glass. In Modern Methods for Analysing Archaeological and Historical Glass, Janssens, K. (Ed.), pp. 515-536. West Sussex: John Wiley \& Sons, Ltd.

Vilarigues, M. \& DA Silva, R.C. (2004). Ion beam and infrared analysis of medieval stained glass. Appl Phys A Mater Sci Processing 79, 373-378.

WEDEPOHL, K.H. \& SiMON, K. (2010). The chemical composition of medieval wood ash glass from Central Europe. Chemie Erde Geochem 70, 89-97. 